\title{
Material flow accounting of Spain
}

\section{Sílvia Cañellas, Ana Citlalic González, Ignasi Puig, Daniela Russi*, Cristina Sendra and Amalia Sojo}

\author{
Universitat Autònoma de Barcelona, \\ Departament d'Economia i d'Història Econòmica, Edifici B, \\ 08193 Bellaterra (Cerdanyola del Vallès), Barcelona, Spain \\ E-mail: anacitlalic.gonzalez@campus.uab.es
}

E-mail: E-mail: ipuig@ent-consulting.com silvia.canellas@uab.es E-mail: daniela.russi@uab.es E-mail: cristina.sendra@uab.es E-mail: asojo@curs.ictnet.es

*Corresponding author

\begin{abstract}
Material throughput is a means of measuring the so-called social metabolism, or physical dimensions of a society's consumption, and can be taken as an indirect and approximate indicator of sustainability. Material flow accounting can be used to test the dematerialisation hypothesis, the idea that technological progress causes a decrease in total material used (strong dematerialisation) or material used per monetary unit of output (weak dematerialisation).

This paper sets out the results of a material flow analysis for Spain for the period from 1980 to 2000. The analysis reveals that neither strong nor weak dematerialisation took place during the period analysed. Although the population did not increase considerably, materials mobilised by the Spanish economy (DMI) increased by 85\% in absolute terms, surpassing GDP growth. In addition, Spain became more dependent on external trade in physical terms. In fact, its imports are more than twice the amount of its exports in terms of weight.
\end{abstract}

Keywords: material flow accounting; Spain; dematerialisation; external trade; environmental Kuznets curve; economic growth; social metabolism.

Reference to this paper should be made as follows: Cañellas, S., González, A.C., Puig, I., Russi, D., Sendra, C. and Sojo, A. (2004) ‘Material flow accounting of Spain’, Int. J. Global Environmental Issues, Vol. 4, No. 4, pp.229-241.

Biographical notes: Sílvia Cañellas received her bachelor’s degree in environmental sciences from Autonomous University of Barcelona (2000). Cañellas spent six months working on a research project at Bergen University, Norway. Her research topic is environmental management.

Ana Citlalic González received her MS in environmental economics and natural resources from UCL, University of London (1997) and a MS in ecological economics and environmental management from Autonomous University of Barcelona (2003). Her research topics are cost-benefit analysis and economic valuation, multi-criteria analysis.

Copyright (C) 2004 Inderscience Enterprises Ltd. Ignasi Puig received his master’s degree in ecological economics and environmental management from Autonomous University of Barcelona (2000) and an MS in modelling, monitoring and management of environmental change from King's College, London. His research topics are environmental taxes and urban waste management.

Daniela Russi received her bachelor's degree in environmental economics from University of Siena, Italy (2001). In 2000, Russi spent five months at the Wuppertal Institute for Climate and Environment, Germany. She received a MS in 
ecological economics and environmental management from the Autonomous University of Barcelona. Her research topics are multi-criteria evaluation and energy policy, material flow accounting and environmental conflicts.

Cristina Sendra received her bachelor's degree in chemical engineering from Autonomous University of Barcelona (2001). In 2001, Sendra spent five months at the Environmental Engineering Department of Politecnico of Milano, Italy. Her research topics are industrial ecology, environmental indicators and material flow accounting.

Amalia Sojo received her master's degree in environmental engineering from University of Barcelona (2000) and she received a MS in ecological economics and environmental management from the Autonomous University of Barcelona (2001). At present, Sojo is working at Instituto Tecnológico de Estudios Superiores de Monterrey, in Puebla (Mexico). Her research topics are life cycle analysis and industrial ecology.

\section{Introduction}

There is burgeoning literature on the topic of environmental Kuznets curve, a hypothesis based on the idea that economic and technological development allows for the reduction of environmental impact of societies (Rothman, 1998). If verified, this hypothesis would lead to important political consequences, in the sense that following the present development path will lead to a more sustainable economic system. This would mean that environmental measures are not necessary, and that instead, the environment would benefit from policies that aim at stimulating the economic growth.

An interesting way to test this hypothesis is to analyse the amount of material used by a country in physical terms. The material used cannot be taken as a direct measure of sustainability: many materials, used in small quantities, such as mercury, can have highly negative effects on the environment. Nevertheless, the

total amount of material used by an economy can give insights into its 'social metabolism '(Fischer-Kowalski, 1998a; 1998b) and can be applied as an indirect measure of the environmental impact. In fact, materials must be extracted and processed in order to produce goods that are then transported, exchanged, used and finally, discharged. All these activities have environmental impacts.

Material flow accounting can be used to test the dematerialisation hypothesis (Bruyn and Opschoor, 1997). According to this theory, countries tend to use less material in absolute terms (strong dematerialisation) or at least per unit of service produced (weak dematerialisation or decoupling) due to technological progress, which is in turn made possible by economic growth. The dematerialisation hypothesis can be seen as a different formulation of the environmental Kuznets curve. In addition, information about a country's level of dependence on materials coming from other economic systems can be of use. Much research has already been carried out in this direction on international (Fischer-Kowalski and Amann, 2001; Bringezu and Schütz, 2001) and national scale (Carpintero, 2002; Alonso and Bailón, 2003).

This paper analyses material flows associated with the Spanish economy between 1980 and 2000. The Eurostat methodology (EUROSTAT, 2001) has been followed in order to ensure comparability with other similar analyses conducted for different countries in Europe (Bringezu and Schütz, 2001), as well as for other countries such as the USA, Japan (Adriaanse et al., 1997) and Brazil (Matthews et al., 2000). The Eurostat methodology produces quite adequate and easy-obtained indicators, providing a first overview on the physical dimensions of a country.

In this framework, a complete balance of an economy can be carried out (Figure 1) by taking into account what crosses the system's boundaries. However, this methodology does not specifically analyse the different sectors of the economy. In other words, the system is regarded as a 'black box.' The basis of the methodology is the first law of thermodynamics which states that - with the exception of nuclear reactions - matter is neither created nor destroyed. Thus the net accumulation of materials in a system can be calculated as the difference between what enters (inputs) the system and what goes out (outputs).

Figure 1 Economy-wide material balance (excluding air and water) 


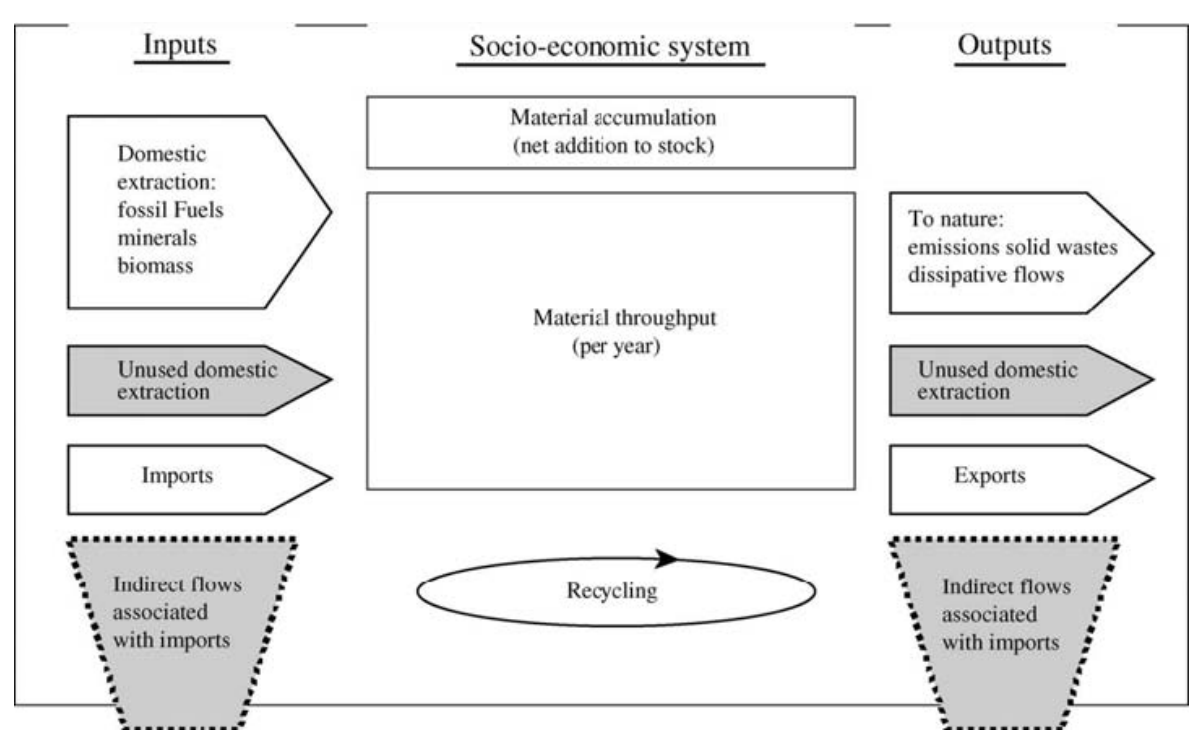

According to the Eurostat classification, material flows can be domestic, if extracted from the system, or $R O W$, if coming from the Rest $O$ f the World. ROW material flows can be direct or indirect. The former enter directly into the system while the latter - the so-called ecological rucksack - are linked to the production of goods, even if these resources are later not exchanged in the market. In addition, both direct domestic and ROW material flows can be used and unused. The latter represent materials extracted or discarded during the production of a good, i.e. mining overburden, while the term used refers to an input for use in the economy.

This paper focuses on direct material inputs, due to the fact that even though indirect flows increase the comprehensiveness of the analysis, they also increase its arbitrariness. This is because indirect flows are calculated by multiplying direct flows by standard coefficients. However, in reality they vary considerably depending on many factors, such as the state of technology and the economic conditions of a country. Moreover, if indirect flows are accounted for, comparisons between countries may imply double-counting internationally traded goods since indirect flows are accounted for twice - in both the exporting and the importing country. It should also be noted that water and air are excluded (although the water and air content present in materials are included), as they represent nearly $95 \%$ of the entire metabolism of an industrial society (Schandl, Weisz and Petrovic, 2000).

In the Eurostat methodological guide (EUROSTAT, 2001) material flows are classified into three main material groups (minerals, energy and biomass) and into three main categories (imports, exports and domestic extraction), which are used to structure the indicators calculated in this study:

- Domestic extraction: Materials extracted in the national territory per year.

- Direct material input (DMI): Domestic extraction (DE) plus direct material imports

(I) $(\mathrm{DMI}=\mathrm{DE}+\mathrm{I}) . . \cdot$ Domestic material consumption $(\mathrm{DMC})$ : DMI minus direct material exports (E) $(\mathrm{DMC}=\mathrm{DMI}-\mathrm{E}=\mathrm{DE}+\mathrm{I}-\mathrm{E})$.

\section{Is Spain dematerialising?}

The Spanish economy has experienced a strong growth in the last twenty years in a path of convergence in income per capita with the older members of the European Union. This period includes

- cycles of recession, stagnation and recuperation . $\bullet$ structural change (due to an increasing predominance of the service sector in terms of employment and economic added value) . $\bullet$ an increasing use of natural resources, this section analyses the impact of this economic performance on material use.

Firstly, strong dematerialisation did not take place since the use of materials steadily increased over this period. For instance, the material moved by the economy, expressed by the direct material input (DMI), increased by $85 \%$ between 1980 and 2000. As can be observed in Figure 2, domestic extraction (DE), domestic material input (DMI) and domestic material consumption (DMC) followed a similar path. Material consumed in Spain (DMC) increased by $78.5 \%$. This tendency has also been observed in the long term. 
Carpintero (2002) gave figures for the total material requirement (TMR) of the Spanish economy showing that it was 4.5 times larger in the 1990s than it was in the 1950s.

Figure 2 Spanish DE, DMI and DMC (1980-2000)

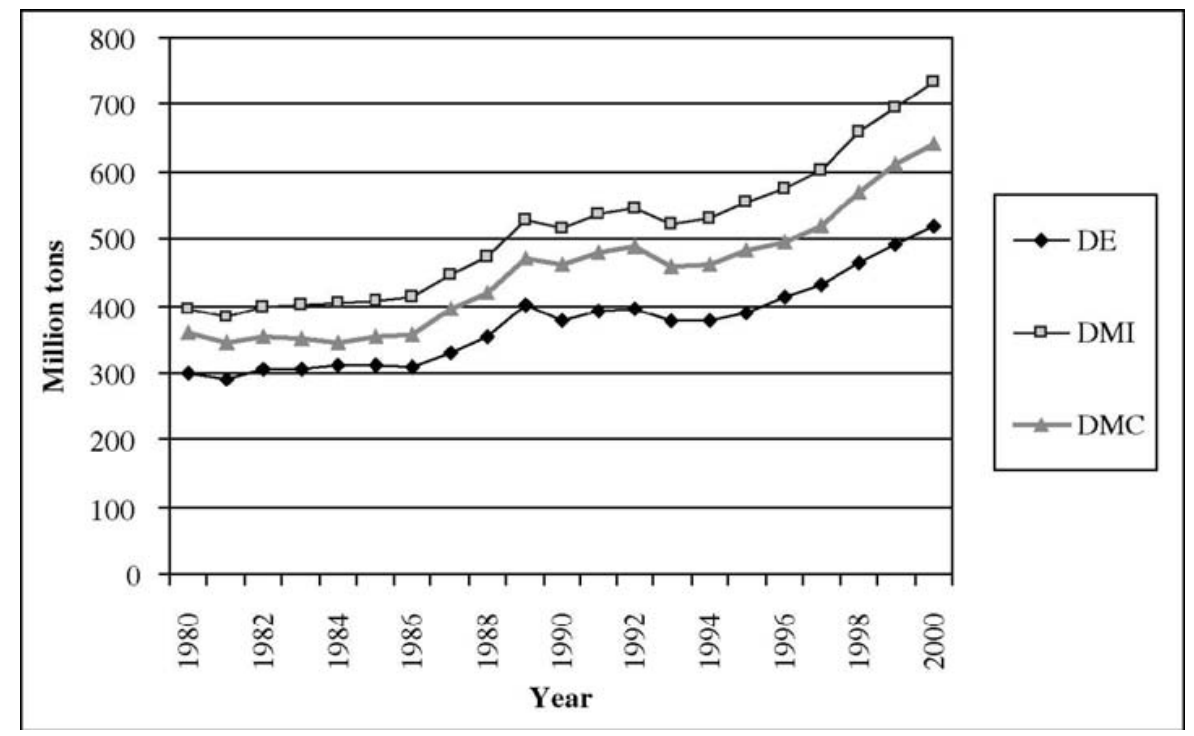

DMC measured in per capita terms increased from 9.5 ton/person in 1990 to 16 ton/person in 2000 while population remained almost stable during this period. The population was 37.5 million in 1980, 38.8 million in 1990 and almost 40 million in 2000. DMC in 2000 was almost twice the value of 1980, thus showing no symptoms of strong dematerialisation at all. In contrast, Spain locked itself into a technological pattern of increased use of materials.

Secondly, weak dematerialisation did not take place in Spain either. While GDP increased by 74\%, DMI increased by $85 \%$. As can be observed, DE, DMC and DMI followed the country's economic cycles: stagnation in the early eighties, followed by a cyclic expansion from 1985 to 1990, a halt from 1992 to 1995, after which a new period of expansion began again. In other words, there are no signs of material consumption detaching from the economic evolution. Figure 3 shows that direct material input (DMI) in

relation to GDP increased by approximately $6 \%$.

In this sense, this trend does not follow the performance of other industrialised countries. In fact, previous analyses have proven that in some industrialised countries a decoupling between GDP and material use took place notwithstanding an increase in material flows in absolute terms (Adriaanse et al., 1997).

As regards the material flows between Spain and the rest of the world, exports grew faster than imports throughout the whole period. As a matter of fact, they increased by 146\% (from 37 to 92 million tons)

whereas imports increased by 124\% (from 96 to 216 million tons). However, since imports weighed more than twice the exports, net imports increased by $110 \%$ (Figure 4). This underlines the fact that the Spanish economy has become more dependent on international trade. The analysis of these figures suggests that Spain is importing a large amount of primary natural resources, which are characterised by high weight, low price and low added value. These types of imports might also imply high levels of pollution and environmental degradation in the countries from which these

materials are extracted (Muradian, O’Connor and Martínez-Alier, 2002). These

hypotheses are to be confirmed on further analyses.

Figure 3 DMI/GDP in Spain (1980-2000) 


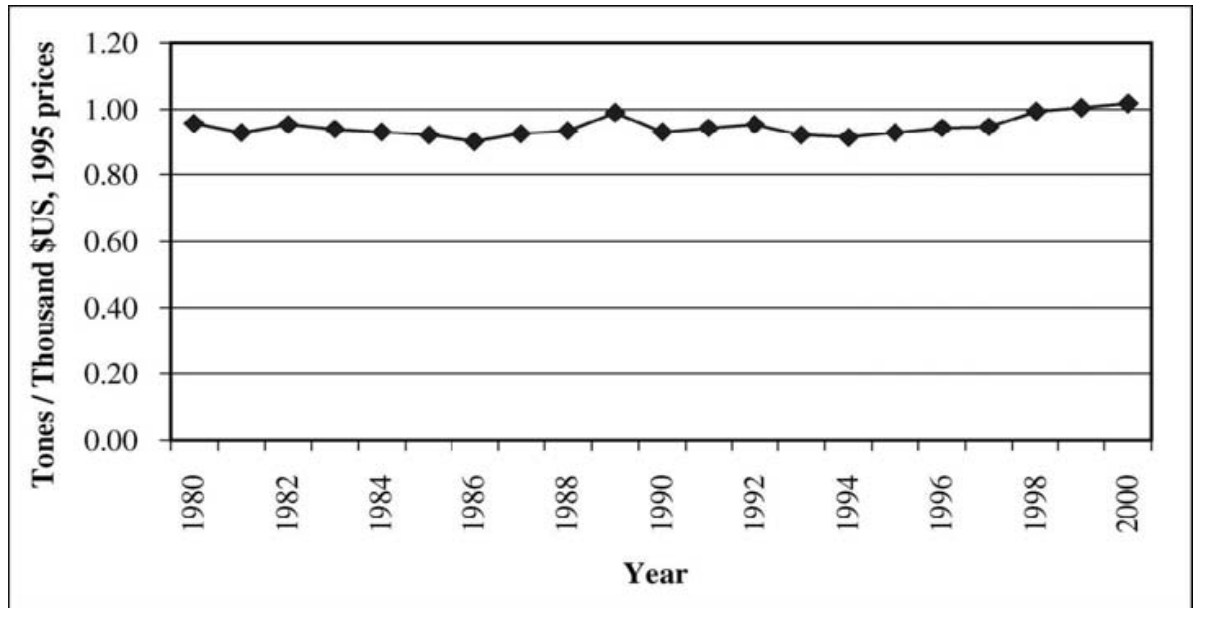

Figure 4 Net imports for Spain (1980-2000)

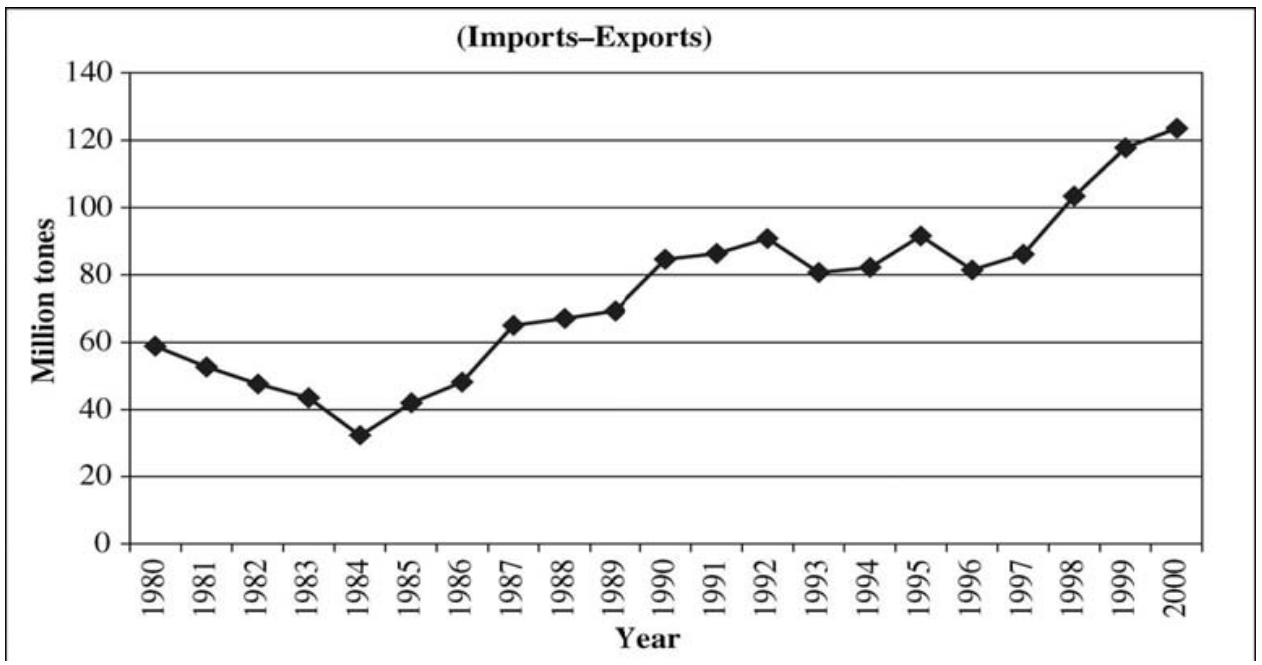

\section{Analysis by material groups}

\subsection{Energy resources}

This part of the analysis considers materials that are transformed for the purposes of energy. At the beginning of the 1980s most of the primary energy consumed was obtained from oil and coal, representing more than $90 \%$. Between 1980 and 2000 the structure of energy production in Spain changed with the increase of other energy sources. Nuclear power production began to rise in 1984, as well as natural gas at the end of the 1980s. In the year 2000, coal and oil represented only $70 \%$.

Renewable energy sources, including hydropower, have not been considered in the analysis below since they do not imply material transformation. Nuclear power is not considered either, due to the relatively small amount of mass needed to produce energy. Thus the analysis focuses on the use of fossil fuels, the most significant energy sources in terms of mass. In this analysis three main categories of fuels are taken into account: coal, crude oil and natural gas.

Coal represents the largest share of domestic extraction of energy resources in Spain. In fact, it accounts for $98 \%$ of total energy extraction in 2000. Spain has few oil and gas reserves, each source accounting for approximately one percent of the total in 2000. Domestic extraction of energy resources has declined since the early 
1980s. This could be due to:

• geographical displacement of energy production abroad (Muradian and MartínezAlier,

2001; Giljum and Eisenmenger, 2004)

• improvements in energy efficiency

. the substitution of coal by oil imports, gas and domestic nuclear power.

In the case of oil and natural gas, although new oil and gas deposits were discovered, domestic extraction decreased (especially since 1990), due to the depletion of previous sites. In any case, the contribution of domestic oil and gas to the total energy production is minimal.

Spain was and continues to be a net importer of energy. Fossil fuel imports have always been larger than exports and they have increased over the period studied. More than $50 \%$ of total imports by weight were energy carriers in 2000. Figure 5 shows the large, increasing share of energy carriers in total imports in per capita terms.

\subsection{Biomass}

Three main types of biomass are considered in this study: agriculture, forestry and fishing. Agriculture has accounted for most of the biomass extraction throughout the period analysed. In 1995 a sharp decline of total biomass extraction occurred due to the droughts in the winter of 1994/1995, which implied a strong decrease in cereal and oil crop production. Overall, total extraction increased by 17\% between 1980 and 2000 (from 86 to 101 million tons).

In $2000,80 \%$ of total extraction of used biomass was constituted of agriculture and grazing. In this same year, domestic extraction of agricultural products was headed by cereals, which represented $35 \%$ of the total crops. Roots and tubers represented $26 \%$ and fruits accounted for another $25 \%$.

Domestic extraction of biomass remained almost stable over the period, in contrast to energy and mineral materials, as can be observed in Figure 5. Direct material input of biomass increased due to imports, which also increased steadily during the period. Domestic material consumption of biomass increased in absolute terms and in per capita terms (from 2.5 to 2.92 ton/capita) all along the analysed period, but the change in consumption in this sector was smaller than it was for the mineral and energy ones. This

indicates that the increased use of materials and energy in Spain concomitant with economic growth has certainly not been fulfilled by domestic or imported biomass. Figure 5 DE, imports and exports per capita in Spain (in tons/capita-year) 

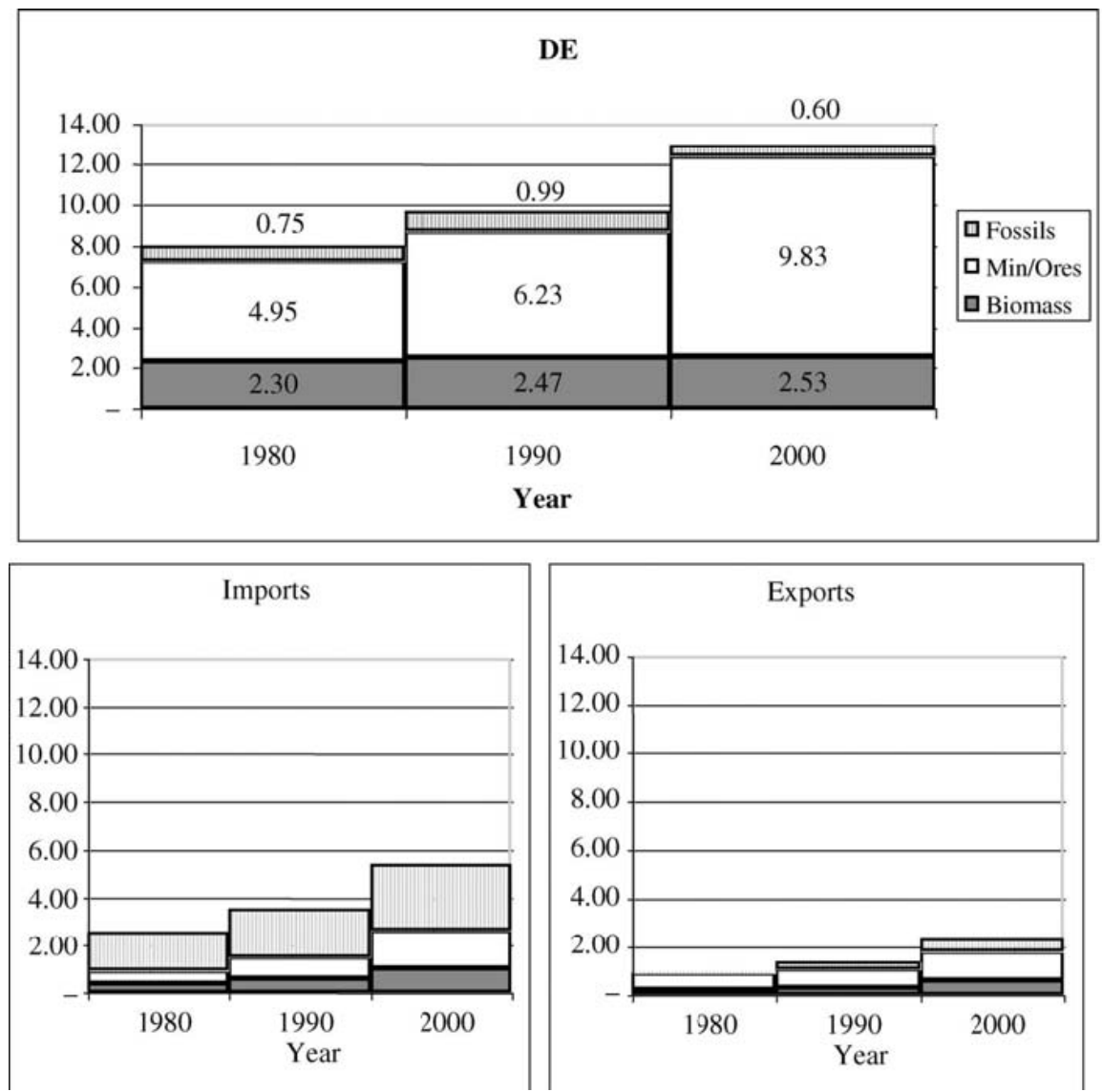

7

\subsection{Minerals}

Minerals constitute the most important material group, with a higher proportion and higher growth rate. This is mainly due to the dynamism of the construction sector, which experienced higher growth rates than the European average (Común, Hernández and Llopis, 2002).

Mineral data were aggregated into three main categories: metal ores, industrial minerals and construction minerals. Industrial minerals and construction minerals comprise non-metallic minerals. They are clearly differentiated from metal ores. However, the difference between industrial and construction minerals is not clearcut. In this analysis, industrial minerals are classified as those that are not bulk materials for construction processes (Figure 6).

Figure 6 Minerals DE (1980-2000) 


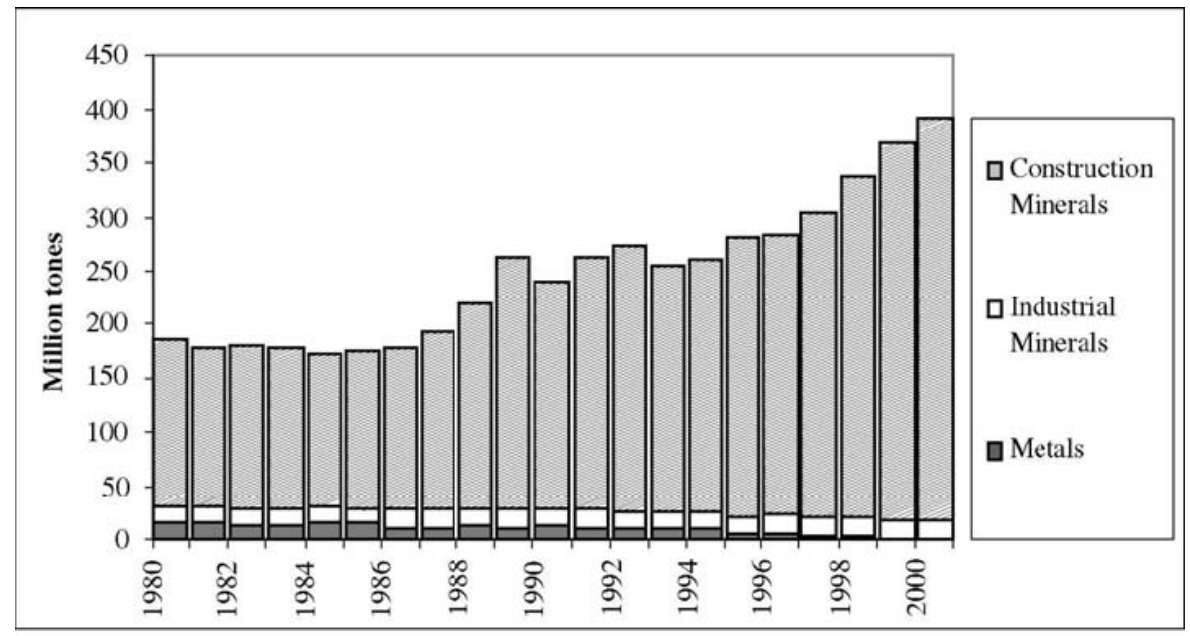

Domestic extraction (DE) of minerals experienced an overall increase during the period 1980 to 2000. In per capita terms, DE grew from 4.85 to 9.83 ton/capita (Figure 5). It is important to point out that mineral DE trend in Spain is dominated by construction minerals. Thus, both industrial minerals and metal ores accounted for $17 \%$ in 1980 and only $5 \%$ in 2000 of the total amount of mineral DE. The construction sector shares of GDP and employment have increased year after year, surpassing the European average.

As a result, domestic extraction of minerals in Spain has doubled in the last 20 years. From 1980 to 1985 it remained approximately steady. In 1986, with economic recovery a period of increase in minerals extraction began. The early 1990s showed an irregular pattern in minerals DE, although there was a slight increase from 1990 to 1996. In this period, even though Spain faced an economic downturn, the construction sector experienced a dynamic boost due to two main events held in 1992: the Olympic Games in Barcelona and the World Exhibition in Seville. The last period (1996-2000) also shows a steady rise in mineral DE.

As previously stated, the DE trend is dominated by the demand of construction minerals. However, industrial minerals and metal ores followed a very different trend. While industrial minerals remained approximately steady throughout the whole period of time considered, metal ores clearly declined, going from

16.32 MT in 1980 to only 1 MT in the year 2000. The decrease experienced by this sector is not related to any economic crisis but to the structural change of the metal sector in Spain that began in the 1980s. During this period, a number of mines and ironworks were shut down and, since then, extraction of metal ores in Spain has become irrelevant.

An analysis of the data from mineral imports and exports for the period 1980 to 2000 shows that Spain shifts from being a net exporter to being a net importer (Figure 7). Unlike in the case of DE, industrial minerals and metal ores account for the majority of imports and exports in this sector. The main single contributors to imports nowadays are iron and steel (as raw materials or in the form of processed goods). The imports of these materials have more than doubled between 1980 and 2000, which is coherent with the decline of their domestic extraction. We are again faced with the displacement of

environmental loads to other countries (Muradian, O’Connor and Martínez-Alier, 2002;

Muradian and Martínez-Alier, 2001; Giljum and Eisenmenger, 2004).

Figure 7 Minerals: exports and imports (1980-2000) 


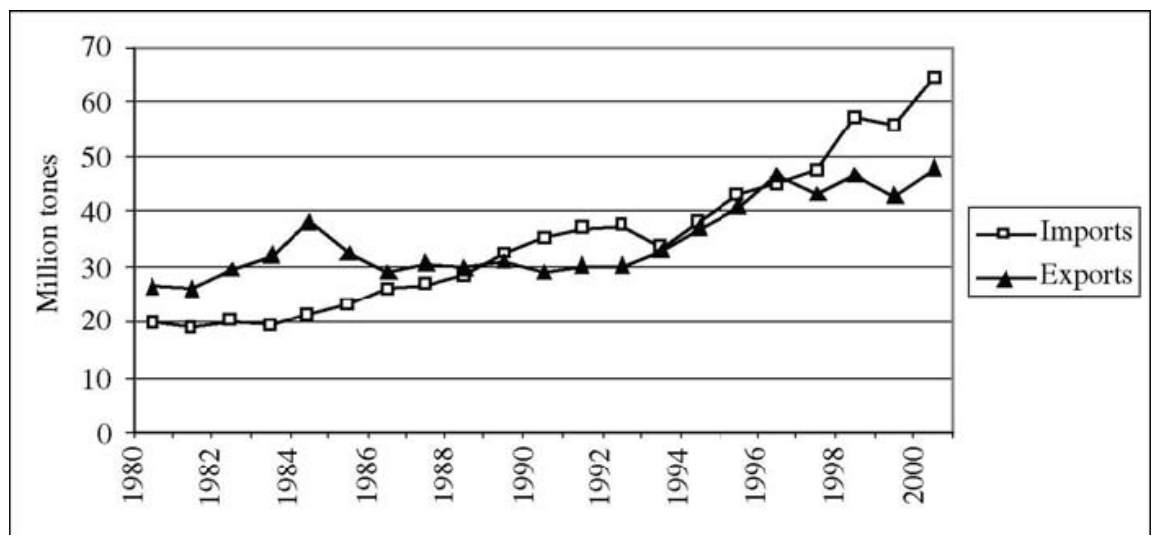

\section{Conclusions}

A number of conclusions concerning the relationship between the Spanish economy and its surrounding environment can be drawn from this analysis. Firstly, the Spanish economy has shown no signs of dematerialisation in absolute terms. In contrast, the total mass of material moved by the Spanish economy (i.e. DMI = domestic extraction plus direct material imports) increased by 85\% from 1980 to 2000, whereas GDP increased by 74\%. Thus, Spain's trend towards convergence of income per capita within the European Union is matched by its 'race to the top' in terms of materials.

Secondly, domestic extraction (DE), consumption (DMC) and material input (DMI) in the economy has evolved in line with the economic cycles. Therefore, there is no evidence of a decoupling trend between economic growth and material use dematerialisation in relative terms.

Thirdly, the Spanish economy has become increasingly dependent on international trade. Imports are twice as much as exports in terms of weight. In other words, Spain is using more and more natural resources from other economic systems to increase its welfare-displacing environmental loads to poorer countries. The dependence on energy imports has been a key characteristic of the Spanish economy. Also, metals that used to be domestically produced are now imported.

As aforementioned, the quantitative analysis performed here does not deal with qualitative aspects of material flows such as toxicity. In this sense, MFA should not be seen as a comprehensive assessment of the environmental impact of an economy. However, it is clear that the increase in material flows reveals an increase in the consumption of internal and external resources, some of them causing high environmental impacts during extraction, transport, use or waste disposal.

Other environmental indicators show trends that are similar to the MFA. For example, $\mathrm{CO}_{2}$ emissions rose

from 5.43 in 1980 to 7.64 metric tons $\mathrm{CO}_{2}$ per person in 2000, an increase of almost $40 \%$. The importance of the construction sector in material flows is also seen in other indicators, such as the number of finished houses and flats constructed

per year, which underwent a 48\% increase between 1990 and 2000. Probably, the importance of the construction sector would also be shown by the comparatively rapid rates of soil sealing in Spain due to new transport infrastructures.

Therefore, this paper should be seen as one of the first attempts to analyse the Spanish economy in terms of material use. Further improvements should be done by exploring the relationship between MFA and assessment of environmental impacts. Definite conclusions on historical trends would need an analysis of broader historical data as well as further evidence from socio-economic, political and technological disciplines that allow explaination of the interrelated dynamics between material flows and the socioeconomic system.

Our finding that Spain has not reached a stage of 'weak dematerialisation' in 2000 should not be construed as 
agreement on our part to the use of environmental indicators based on intensive variables such as energy intensity or carbon emissions intensity or volume of transport relative to GNP or indeed material intensity (material per unit of GNP). The environment, so to speak, does not care about GNP.

\section{Acknowledgments}

We are grateful to Joan Martínez-Alier and Heinz Schandl for comments and to the Department of Social Ecology of the Institute for Interdisciplinary Studies of Austrian Universities (IFF) for providing us with the methodology used in this paper during the course 'Material and Energy Flow Accounting', held in Vienna in March 2002, partially funded by the Integrated Action between the Autonomous University of Barcelona (UAB) and IFF under the contract HU2000-0025.

\section{References}

Adriaanse, A., Brigenzu, S, Hammond, A., Moriguchi, Y., Rodenburg, E., Rogich, D. and Schütz,

H. (1997) 'Resource flows', The Material Basis of Industrial Economies, World Resource Institute, Washington DC. Alonso, F. and Bailón, L. (2003) 'Balance y cuentas de flujos de materiales', Documentos de Trabajo 3/03, INE, Madrid. Bringezu, S. and Schütz, H. (2001) 'Total material requirement of the European Union', in European Environmental Agency (Ed.): Technical Report No 55, EEA, Copenhagen. Bruyn, S.M. and Opschoor, J.B. (1997) 'Developments in the throughputincome relationship: theoretical and empirical observations’, Ecological Economics, Vol. 20, pp.255268. Carpintero, O. (2002) ‘La economía española: el ‘dragón europeo’ en flujos de energía, materiales y huella ecológica, 1955-1995’, Ecología Política, Vol. 23, pp.85-125. Común, F., Hernández, M. and Llopis, E. (Eds.) (2002) ‘Historia económica de españa’, Siglos $X$ - $X X$, Editorial Crítica.

EUROSTAT (2001) Economy-Wide Material Flow Accounts and Derived Indicators - a Methodological Guide, Office for Official Publications of the European Communities, Luxembourg.

Fischer-Kowalski, M. (1998a) 'Society’s metabolism. The intellectual history of material flow analysis, Part I, 1860- 1970’, Journal of Industrial Ecology, Vol. 2, No. 1, pp.61-78. Fischer-Kowalski, M. (1998b) 'Society's metabolism. The intellectual history of material flow analysis Part II, 1970 1998', Journal of Industrial Ecology, Vol. 2, No. 4, pp.107-136.

Fischer-Kowalski, M. and Amann, C. (2001) 'Beyond IPAT and kuznets curves: globalization as a vital factor in analysing the environmental impact of socio-economic metabolism’, Population and Environment, Vol 23, No.1, pp.7-47.

Giljum, S. and Eisenmenger, N. (2004) 'North-South trade and the distribution of environmental goods and burdens: a biophysical perspective’, The Journal of Environment \& Development, March, Vol. 13, No. 1, pp.73-100 (28).

Matthews, E., Amann, C., Brigenzu, S., Fischer-Kowalski, M., Hütler, W., Kleijn, R., Moriguchi, Y., Ottke, C., Rodenburg, E., Schandl, H., Schütz, H., van den Voet, E. and Weisz, H. (2000) 'The weight of nations', Material Outflows from Industrial Economies, World Resource Institute, Washington DC.

Muradian, R. and Martínez-Alier, J. (2001) 'Trade and the environment from a southern perspective’, Ecological Economics, Vol. 36, pp.281-297.

Muradian, R., O’Connor, M. and Martínez-Alier, J. (2002) 'Embodied pollution in trade: estimating the 'environmental load displacement' of industrialised countries', Ecological Economics, Vol. 41, pp.51-67. Rothman, D.S. (1998) 'Environmental kuznets curves - real progress or passing the buck? A case for consumption-based approaches’, Ecological Economics, Vol. 25, pp.177-194. Schandl, H., Weisz, H. and Petrovic, B. (2000) 'Materialflussrechnung für Österreich 1960 bis 1997', Statistische Nachrichten, Vol. 55, No. 2, pp.128-137.

Spanish National Statistics: La Energía en España (2002) 'Dirección general de política energética y minas (general direction of energetic policy and mines), secretaria de estado de energia desarrollo industrial y de la pequeña y mediana empresa’, Ministry of Economy, Spain, 2003. 


\section{Bibliography}

Spanish National Statistics: La energía en España (2001) 'Dirección general de política energética y minas (general direction of energetic policy and mines)’, Ministry of Economy, Spain.

\section{Notes}

1 This metaphor is used to express that an economy is seen as an organism that takes resources from the outside and discharges wastes.

2 TMR = direct material input + unused material extraction + indirect flows associated with imports.

3 GDP data obtained from OECD online statistical databases. www.oecd.org

4 The data on foreign trade comes from the Spanish Foreign Trade Statistics. Estadística del Comercio Exterior de España. Volumen I: comercio por países y por productos, published by the Spanish Ministry of Economy and Finance. Years 1986-2000.

$5 \quad$ The data on energy are taken from the Spanish National Statistics: La Energía en España, 2002.

6 All data used to calculate biomass flow through Spanish economy have been obtained from FAO statistics (FAOSTAT. Agriculture Database, 1980-2000), verified and compared with national data published by the Spanish Ministry of Agriculture, Fisheries and Food (Anuario de Estadística Agroalimentaria).

7 Data used for the mineral fraction of the MFA have been taken from the Spanish National Statistics: Estadística Minera de España, published by the Ministry of Industry and Energy (MINER) for the period 1980 to 1998, and by the Ministry of Economy (MINECO) for 1999 and 2000.

8 Emissions per capita have been calculated using Total Emissions of $\mathrm{CO}_{2}$ (excluding land-use). World Resources Institute (2003), Carbon Emissions from Energy Use and Cement Manufacturing, 1850 to 2000. Available online through the Climate Analysis Indicators Tool (CAIT) at http://cait.wri.org. World Resources Institute, Washington, DC.

9 Anuario Estadístico de España. Instituto Nacional de Estadística (Spanish Institute of Statistics). Available online at http://www.ine.es. 